\title{
Perkembangan dan Faktor-Faktor yang Mempengaruhi Pola Pangan Harapan Daerah Istimewah Yogyakarta
}

\author{
Musta'in', Wahyu Adhi Saputro \\ 1) Program Studi Keperawatan, Fakultas Ilmu Kesehatan, Universtas Duta Bangsa Surakarta, \\ 2) Program Studi Agribisnis, Fakultas Sains dan Teknologi, Universtas Duta Bangsa Surakarta, \\ email: mustain@udb.ac.id ${ }^{1}$,wahyuadhi@udb.ac.id²
}

\begin{abstract}
ABSTRAK
Skor pola pangan harapan akan meningkat apabila ketahanan pangan juga meningkat. Dalam hal ini keanekaragaman pangan adalah salah satu pilar dalam pemenuhan ketahanan pangan. Keanekaragaman pangan baik mutu dan gizi yang cukup merupakan salah satu prasyarat pokok dalam konsumsi kebutuhan pangan. Daerah Istimewa Yogyakarta merupakan salah satu daerah yang pesat perkembangannya khususnya kependudukan. Pertambahan penduduk Daerah Istimewa Yogyakarta tiap tahunnya yang jumlahnya tidak menentu. Pertambahan penduduk di DIY terjadi baik secara alami maupun migrasi. Dengan demikian terjadi peningkatan berbagai maca tuntutan kebutuhan khususnya pangan sehingga kebutuhan akan pangan menjadi salah satu hal penting yang harus diperhatikan. Tujuan penelitian ini untuk menggambarkan perkembangan pola pangan harapan in DIY dan menganalisis faktor yang mempengaruhi pola pangan harapan di DIY. Penelitian in menggunakan metode deskriptif analitik dan analisis regresi berganda menggunakan data time series. Tipe data yang digunakan adalah data sekunder dari Badan Pusat Statistik. Pola pangan harapan Daerah Istimewa Yogyakarta cenderung mengalami peningkatan dari tahun ketahun kecuali pada tahun 2019 mengalami penurunan sebanyak 6,6\%. Prediksi pola pangan harapan Daerah Istimewa Yogyakarta mengalami kenaikan pada tahun 2020 sebanyak 3,4\% dibanding tahun sebelumnya. Hasil penelitian menunjukan bahwa faktor yang berpengaruh terhadap pola pangan harapan adalah jumlah pengeluaran rumah tangga, besaran anggota keluarga dan tingkat pendidikan.
\end{abstract}

Kata Kunci: Pangan, Ketahanan Pangan, Pola Pangan Harapan

\section{PENDAhuluan}

Konsumsi pangan merupakan output pembangunan ketahanan pangan di suatu wilayah. Oleh karena itu, penganekaragaman konsumsi pangan merupakan isu penting yang harus ditingkatkan upaya pencapaiannya (Argandi dkk, 2019). Penyelenggaraan upaya kesehatan bangsa Indonesia dalam menggapai kemampuan untuk hidup sehat merupakan artian dari pembangunan kesehatan dan salah satu kesejahteraan umum dan tujuan nasional. Hakikatnya kesehatan memegang peranan penting untuk peningkatan kesejah teraan manusia. Hal tersebut sama halnya dengan permasalahan kesehatan yang dihadapi untuk membangun sumber daya manusia diperuntukan untuk sumber daya pembangunan (Budioro B, 2002:18). Tujuan peningkatan kesehatan salah satu caranya dapat dilakukan dengan peningkatan gizi masyarakat sehingga ketahanan, ketersediaan, keterjangkauan, dan distribusi pangan harus baik. Beberapa periode telah menyinggung adanya diversifikasi pangan, pengolahan pangan dan pengubahan kultur pangan terutama nasi karena notabene konsumsi nasi sangat tinggi di Indonesia. Akan tetapi komitmen diversifikasi pangan yang diterapkan oleh komitmen pemerintah masih sangat rendah (Sunyoto Usman, 2004:13).

Pangan merupakan kebutuhan yang paling mendasar bagi sumber daya manusia suatu bangsa. Pencapaian ketahanan pangan suatu negara dinilai ketika tercapainya ketersediaan pangan yang cukup baik dari segi kualitas dan kuantitasnya. Distribusi pangan dengan harga terjangkau dan keamanan pangan juga merupakan salah satu faktor pemenuhan ketahanan pangan. Pola Pangan Harapan (PPH) adalah 
susunan jumlah pangan menurut sembilan kelompok pangan yang didasarkan pada kontribusi energi yang memenuhi kebutuhan gizi secara kuantitas, kualitas maupun keragaman pangan dengan mempertimbangkan aspek sosial, ekonomi, budaya, agama, dan cita rasa (Amaliyah, 2011). Kurun waktu lima tahun PPH Nasional mengalami penurunan pada tahun 2012 dan 2013 berkisar pada skor 83,5 dan 8,14 jika dibandingkan pada tahun 2011 mencapai skor 85,6. Tahun 2015 skor PPH juga mengalami peningkatan jika dibandingkan dengan tahun 2014 menjadi 85,2 (Badan Ketahanan Pangan, 2016).

Instrumen sederhana sebagai penilaian situasi konsumsi pangan penduduk merupakan pengertian dari Skor Pola Pangan Harapan (Pph). Penilaian atau skor baik jumlah maupun konsumsi pangan dikategorikan menurut jenis pangan yang dikonsumsi dan dinyatakan dalam skor PPH. Skor ini merupakan indikator mutu gizi dan keragaman konsumsi pangan (Kementerian Pertanian, 2010). Pola konsumsi masyarakat Indonesia memang belum beragam berdasarkan Data Statistik Ketahanan Pangan 2014. Hal tersebut digambarkan dari konsumsi terbesar masyarakat Indonesia yang berasal dari padipadian sebanyak 58\%. Disusul konsumsi umbi umbian sebanyak 1,9\% yang idealnya adalah $6 \%$. Hal tersebut karena lemahnya diversifikasi pangan di Indonesia. Peningkatan impor pangan Indonesia pada periode 2010-2013, kecuali bawang merah, jagung, kedelai dan gandum, rata-rata mengalami kenaikan impor lebih dari 100\% bahkan hingga 400\%. Sedangkan Impor beras meningkat menjadi 482\%, daging sapi $349 \%$, cabai $141 \%$ dan gula $114 \%$. Ketahanan pangan Indonesia mengalami penurunan pada tahun 2012 berada pada peringkat 72 dari 109, akan tetapi pada tahun 2014 menjadi peringkat 70 (Bappenas, 2014).

Data Badan Ketahanan Pangan Nasional tahun 2016 menunjukkan bahwa konsumsi di beberapa daerah sentra produksi pangan cenderung memiliki kualitas konsumsi pangan penduduk yang rendah. Kondisi pendapatan yang terbatas membuat seseorang mendahulukan prioritas kepada kebutuhan makanan. Hal tersebut membuat kelompok masyarakat dengan pendapatan di bawah rata-rata (rendah) akan mengalokasikan pendapatannya untuk konsumsi pangan. Pemenuhan kebutuhan konsumsi makanan merupakan hal yang mutlak dilakukan. Konsumsi pangan rumah tangga dipengaruhi oleh seberapa besar pendapatan yang diperoleh buruh. Salah satu faktor penting dalam mengembangan kualitas sumber daya manusia yaitu kecukupan gizi. Sumber makanan yang masuk ke dalam tubuh manusia sering dikaitkan dengan kecukupan gizi. Wujud dari sumber daya manusia yang berkualitas menjadi prioritas saat menghadapi persaingan di era global. . Kualitas konsumsi pangan seseorang dapat dievaluasi dengan menggunakan skor Pola Pangan Harapan (Aneftasari dkk, 2016)

Setiap siklus kehidupan manusia yang terlewati harus selalu dilakukan perbaikan dan peningkatan gizi di setiap fasenya. Salah satu negara yang belum mencapai indikator yang ditargetkan oleh MDGs adalah Indonesia. Indikator tersebut ditunjukkan dengan proporsi penduduk dengan asupan kalori yang masih berada di tingkat konsumsi minimum (Bappenas, 2014). Kondisi ini salah satunya di indikasikan oleh masih tingginya prevalensi stunting di Indonesia yang masih belum membaik, bahkan mengalami peningkatan (Suryana, et al, 2016). Konsumsi pangan menujukkan cerminan dari ketersedian pangan. Jika pangan yang tersedia belum cukup beragam, maka pangan yang dikonsumsi tidak akan beragam. Bahkan skor keragaman konsumsi pangan merupakan prediktor stunting yang kuat pada anak balita di Bangladesh (Rah et.al, 2010). Tidak mengonsumsi makanan yang beranekaragam akan dapat mengakibatkan tidak terpenuhinya kecukupan energi dan zat gizi yang dibutuhkan oleh tubuh, dan bila kondisi ini terus berlanjut maka akan berdampak signifikan terhadap kondisi gizi masyarakat pada berbagai sasaran, terutama pada masa diawal pertumbuhan dan perkembangan anak. Situasi tersebut merupakan peristiwa yang sangat kompleks dan dipengaruhi berbagai faktor gizi, dan faktor lingkungan, pengetahuan ibu, ketersediaan pangan bahkan tingkat sosial ekonomi keluarga (Al Rahmah, 2016: Al Rahmah, 2017). 
Salah satu negara di Asia sedang menghadapi masalah gizi adalah Indonesia. Permasalahan yang dihadapi adalah gizi kurang dan gizi buruk. Penelitian mengenai status gizi memperkuat hal tersebut dengan adanya penurunan gizi. Tercatat di tahun 2007 terjadi penurunan sebanyak 18,4\% menjadi 17,9\% di 2010. Peningkatan terjadi pada tahun 2013 menjadi 19,6\%. \%. Prevalensi gizi buruk di Indonesia pada tahun 2007 sebesar 5,4\%, menurun di tahun 2010 menjadi 4,9\%, kemudian meningkat pada tahun 2013 menjadi 5,7\% (Kemenkes, RI, 2015). Angka standar dunia prevalensi gizi buruk-kurang berada diantara $20-29 \%$ terjadi masalah kesehatan masyarakat serius, apabula $\geq 30 \%$ dianggap prevalensi sangat tinggi (WHO, 2013).Prevalensi gizi kurang dan gizi buruk pada balita Indonesia telah mencapai 19,6\% merupakan angka yang mendekati standar dunia, ini merupakan masalah kesehatan masyarakat yang perlu diperhatikan (Latifah dkk, 2018).

Perkembangan pola pangan harapan Daerah Istimewa Yogyakarta dapat dilihat dari pola konsumsi masyarakatnya. Perkembangan dinilai dari perubahan skor pola konsumsi pangan masyarakat baik konsumsi pangan padi-padian, umbi-umbian, pangan hewani, minyak dan lemak, buah, kacangkacangan, gula, sayur dan lainya kemudian diwujudkan dalam skor pola pangan harapan. Penilaian faktorfaktor yang berhubungan dengan pola pangan harapan digunakan landasan teori dari definisi pola pangan harapan, kemudian faktor tersebut dikelompokkan menjadi beberapa faktor yaitu besaran anggota keluarga, tingkat pendidikan keluarga dan pengeluaran perkapita. Penelitian ini bertujuan untuk mengetahui pekembangan pola pangan harapan di DIY dan faktor-faktor yang mempengaruhinya.

\section{METODE PENELITIAN}

Penelitian ini dilakukan di Daerah Istimewa Yogyakarta. Penentuan lokasi penelitian dilakukan secara sengaja. Metode purposive merupakan teknik penentuan lokasi dengan menggunakan beberapa pertimbangan tertentu (Sugiyono, 2012). Pemilihan lokasi didasari dengan banyaknya jumlah penduduk di DIY sehingga akan berbanding lurus dengan ketersediaan pangan yang ada di DIY. Menjawab tujuan perkembangan pola pangan harapan di DIY menggunakan metode eksplanasi dan deskriptif analitik. metode eksplanasi (Eksplanatory Research) yaitu apabila peneliti menjelaskan hubungan atau pengaruh kausal antara variabel variabel melalui pengujian hipotesis maka dinamakan penelitian penjelasan (Singarimbun, 2003). Jenis data yang digunakan adalah data sekunder. Sumber data diperoleh dari data sekunder yang dikeluarkan oleh Badan Pusat Statistik Daerah Istimewa Yogyakarta tahun 2016 hingga tahun 2019. Bentuk penelitian verifikatif digunakan untuk menguji hipotesis yang menggunakan perhitungan statistik (Nazir, 1988). Menjawab tujuan kedua mengenai faktor-faktor yang mempengaruhi pola pangan harapan DIY menggunakan analisis regresi berganda. Menurut Drapper dan Smith (1992) metode untuk meramalkan pengaruh dua variabel indpenden atau lebih terhadap variabel dependen disebut analisis regresi berganda. Analisis ini bertujuan untuk membuktikan ada atau tidaknya hubungan antara dua variabel atau lebih dari dua variabel independen $\mathrm{X} 1, \mathrm{X} 2, \mathrm{X} 3, \ldots ., \mathrm{Xi}$ terhadap satu variabel terikat Y. Untuk mengestimasi digunakan model analisis regresi linier berganda. Pengujian model regresi dilakukan dengan menggunakan program Eviews. Perhitungan akan lebih mudah jika persamaan di atas ditransformasikan ke dalam logaritma sehingga menjadi persamaan sebagai berikut:

$$
L_{n} Y=L_{n} \beta_{0}+\beta_{1} \operatorname{Ln} X_{1}+\beta_{2} \operatorname{Ln} X_{2}+\beta_{3} \operatorname{Ln} X_{3}+e
$$

dimana:

$\mathrm{Y} \quad=$ Pola Pangan Harapan

$X_{1} \quad=$ Pengeluaran Perkapita

$X_{2}=$ Besaran Keluarga 
$X_{3} \quad=$ Tingkat pendidikan

$\beta_{0} \quad=$ Konstanta

$\beta_{1,2,3,4,5}=$ Koefisien regresi

e $\quad=$ Error

\section{HASIL DAN PEMBAHASAN}

\section{Perkembangan Skor Pola Pangan Harapan Daerah Istimewa Yogyakarta}

Penggambaran kondisi keberagamaan ada dan tersedianya pangan suatu wilayah secara makro dapat diukur dengan adanya pola pangan harapan. Pola pangan harapan akan ketersediaan pangan adalah jenis dan jumlah kelompok pangan utama yang dianjurkan untuk memenuhi lebutuhan energi dan gizi (FAORAPA, 1998). Adanya pola pangan harapan diharpkan terciptanya rasionalisasi pola ketersediaan pangan yang ada untuk perbaikan kualitas hidup penduduk dan didasarkan sebagai perencanaan dan evaluasi pembangunan pangan. Penilaian ketersediaan pangan berdasarkan jumlah, kualitas/mutu, keseimbangan pemenuhan gizi konsumsi dan komposisi pangan. Pola pangan harapan sering kali dikaitkan dengan konsumsi pangan masyarakat. Pola pangan harapan selaras dengan disertainya Neraca Bahan Makanan (NBM). Harapannya terjadi keseimbangan antara keberagaman pangan yang ada dan dikonsumsi oleh masyarakat. Skor pola pangan harapan dari ke tahun diharapkan naik hingga ke skor maksimal 100. Berikut tabel 1 mengenai skor perkembangan pola pangan harapan Daerah Istimewa Yogyakarta.

Tabel 1. Perkembangan Skor Pola Pangan Harapan Daerah Istimewa Yogyakarta

\begin{tabular}{llcccc}
\hline \multirow{2}{*}{ No } & \multicolumn{1}{c}{ Elemen/Kategori } & \multicolumn{4}{c}{ Tahun } \\
\cline { 3 - 6 } & & 2016 & 2017 & 2018 & 2019 \\
\hline 1 & Pola Konsumsi Padi-padian & 25,00 & 25,00 & 25,00 & 25,00 \\
2 & Pola Konsumsi Umbi-umbian & 1,20 & 1,40 & 0,90 & 1,40 \\
3 & Pola Konsumsi Pangan Hewani & 24,00 & 24,00 & 24,00 & 24,00 \\
4 & Pola Konsumsi Minyak dan Lemak & 4,70 & 4,70 & 5,00 & 4,80 \\
5 & Pola Konsumsi Buah/Biji Berlemak & 1,00 & 1,00 & 0,80 & 1,00 \\
6 & Pola Konsumsi Kacang-Kacangan & 7,00 & 7,20 & 7,30 & 7,40 \\
7 & Pola Konsumsi Gula & 2,50 & 2,50 & 2,50 & 2,50 \\
8 & Pola Konsumsi Sayur dan Buah & 23,10 & 23,20 & 30,00 & 23,80 \\
\hline
\end{tabular}

Sumber: BPS DIY, 2019

Berdasarkan tabel 1 mengenai skor pola pangan harapan Daerah Istimewa Yogyakarta dapat diketahui pemenuhan skor tertinggi masih terdapat pada pola konsumsi padi-padian dari tahun ke tahun tetap konstan sebesar 25.Hal ini memang tidak luput dari kebiasaan masyarakat di Indonesia terutama di DIY sering mengkonsumsi nasi lebih banyak dibandingkan pola konsumsi pangan yang lain. Hal tersebut juga didukung dengan adanya kebiasaan orang jawa yang biasanya belum merasa makan jika belum mengkonsumsi nasi. Pemenuhan kebutuhan pangan selanjutnya dipenuhi dari pola konsumsi pangan hewani yang juga konstan dari tahun ke tahun sebesar skor 24. Pangan hewani yang dimaksud dipenuhi dari konsumsi daging ayam, daging sapi, telur dan masih banyak lainya lagi. Posisi ketiga pemenuhan pola pangan harapan diisi dari pola konsumsi sayur dan buah yang cenderung meningkat dari tahun ke tahun kecuali pada tahun 2019. Pada tahun 2018 pola konsumsi sayur dan buah sudah pada kondisi optimum sebesar skor 30. Jika dilihat dan diperhatikan lebih lanjut pada tabel 1 terlihat sekali pola konsumsi masyarakat Daerah Istimewa Yogyakarta cenderung sama dari tahun ke tahun. Hal tersebut mengindikasikan bahwa pola konsumsi masyarakat DIY kurang beragam dalam mengkonsumsi pangan. 
Keberagaman pangan yang dikonsumsi oleh masyarakat didasari dari ketersediaan pangan yang ada di daerah tersebut. Secara alami masyarakat mengkonsumsi apa yang ada di daerah tempat tinggalnya. Kondisi tersebut juga mengindikasi dibutuhkannya hasil analisis pola pangan harapan yang baik di setiap tahunnya. Skor pola pangan harapan yang ada pada tabel 1 dapat digunakan sebagai roadmap penyediaan keberagaman pangan dengan skor maksimal 100 untuk pola pangan harapan. Peningkatan penyediaan kelompok pangan selain padi-padian seperti umbi-umbian dan kacang-kacangan juga harus ditingkatkan. Penyebabnya adalah pola konsumsi pangan masyarakat DIY prioritasnya adalah padi-padian. Terdapat dua indikasi mengapa masyarakat DIY tidak mengkonsumsi umbi-umbian dan kacang-kacangan sesuai dengan standard yang ada yaitu tidak tersedianya pangan yang berasal dari umbi-umbian atau kacangkacangan atau karena harga umbi dan kacang-kacangan berada di atas padi-padian. Rekomendasi akan hal tersebut adalah peningkatan produksi umbi-umbian terutama umbi lokal seperti ketela pohon secara berkelanjutan atau memberikan bantuan kepada petani untuk menanam umbi-umbian atau kacangkacangan. Selama ini petani di DIY enggan menanam umbi-umbian dan kacang-kacangan karena harga jual dari petani masih rendah sehingga petani masih memprioritaskan menanam padi. Berdasarkan tabel 1 dari skor PPH ketersediaan pangan, keberagaman ketersediaan pangan di Provinsi DIY belum cukup beragam dari tahun 2016 hingga tahun 2019. Peramalan perlu dilakukan untuk melihat apakah pada tahun 2020 skor pola pangan harapan akan meningkat dari tahun sebelummya atau tidak. Perkembangan skor pola pangan harapan dapat dilihat pada grafik 1 .

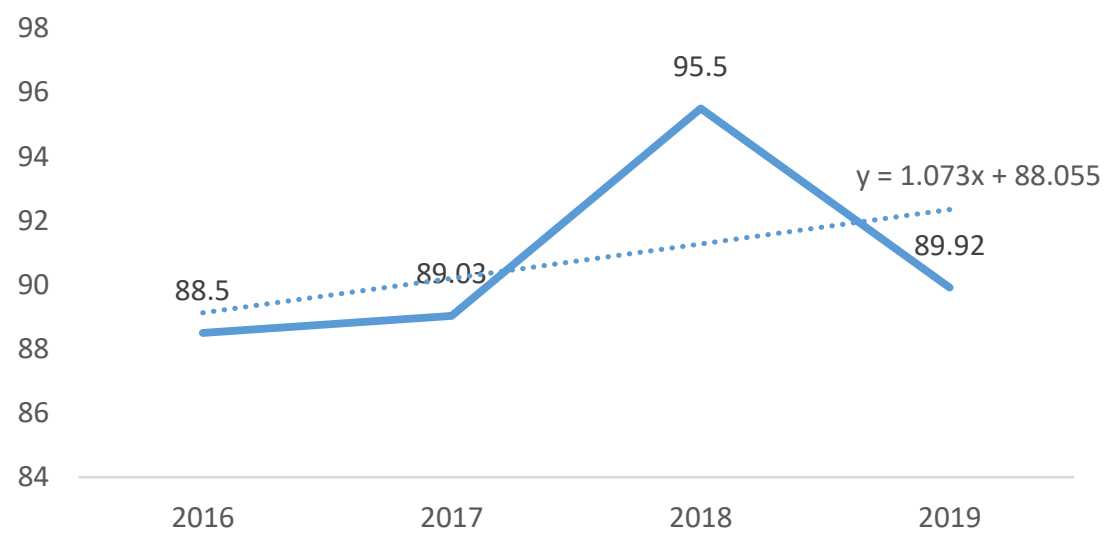

Grafik 1. Fluktuasi Perkembangan Skor Pola Pangan Harapan DIY Tahun 2016-2019 Sumber: Analisis Data Sekunder BPS DIY, 2020

Berdasrkan grafik 1 mengenai perkembangan skor pola pangan harapan DIY pada tahun 20162019 dapat diketahui bahwa skor tertinggi terjadi pada tahun 2018 dengan skor 95,5. Skor pola pangan harapan DIY berada di atas skor pola pangan harapan nasional. Contohnya saya di tahun 2016 skor pola pangan harapan nasional berada pada skor 86 sementara itu skor pola pangan harapan DIY berada pada skor 88,5. Tahun 2018 skor pola pangan harapan DIY berada pada skor 95,5 sementara itu skor pola pangan harapan nasional berada pada skor 90,1. Penurunan terhadap skor pola pangan harapan nasional terjadi pada tahun 2019 berada pada skor 89,92 sementara skor nasional berada pada skor 90. Jika melihat trendline pada grafik 1 dengan nilai $\mathrm{y}=1,073 \mathrm{x}+88,055$ maka dapat diperkirakan pada tahun 2020 skor pola pangan harapan Daerah Istimewa Yogyakarta berada pada 93,42.

Peningkatan pemahaman mengenai pentingnya hasil analisis pola pangan harapn harus ditingkatkan sehingga masyarakat bisa membuat skala dalam konsumsi pangan hariannya dan harapanya 
skor pola pangan harapan suatu daerah lebih tinggi dari skor pola pangan harapan nasional. Adanya pemahaman terhadap skor pph juga dapat memberikan informasi data dengan dinas-dinas terkait yang menangani ketahanan pangan dalam pengadaan ketersediaan pangan daerah masing-masing khususnya Daerah Istimewa Yogyakarta. Setiap tahun ke tahun jumlah penduduk akan meningkat sehingga pangan yang harus disediakan juga harus seimbang dengan penambahan jumlah penduduk tersebut. Solusi dengan meningkatkan produksi pangan juga menjadi salah satu jawaban akan masalah tersebut. Skor pola pangan harapan juga dijadikan bahan pertimbangan pengambilan kebijakan penyediaan pangan tahun berikutnya.

\section{Faktor-Faktor yang Mempengaruhi Pola Pangan Harapan}

Tabel 2 Hasil Analisis Regresi Faktor-faktor yang Mempengaruhi Pola Pangan Harapan DIY

\begin{tabular}{llccc}
\hline No. & \multicolumn{1}{c}{ Faktor Produksi } & Koefisien Regresi & Std.Error & Probability $t$ \\
\hline 1 & Konstanta & $-7,32$ & 0,289 & 0,002 \\
2 & Pengeluaran Perkapita $\left(\operatorname{Ln} X_{1}\right)$ & $2,86^{* * *}$ & 0,070 & 0,001 \\
3 & Besaran Keluarga $\left(\operatorname{Ln~} X_{2}\right)$ & $-0,15^{* *}$ & 0,005 & 0,023 \\
4 & Tingkat Pendidikan $\left(\operatorname{Ln} X_{3}\right)$ & $0,42^{* *}$ & 0,014 & 0,018 \\
\hline & Adjusted $\mathrm{R}^{2}$ & 0,97 & & \\
\hline$\quad$ Fhit & 6,18 & & \\
\hline$\quad$ Probability $F$ & $0,02^{* *}$ & & \\
\hline
\end{tabular}

Sumber : Analisis Data Sekunder, 2020

Berdasarkan tabel 2 dapat diketahui nilai analisis regresi berganda faktor-faktor yang mempengaruhi pola pangan harapan di Provinsi DIY. Berdasarkan nilai Adj $\mathrm{R}^{2}$ adalah 0,97 sehingga dapat diartikan bahwa sebanyak 97\% variasi dari variabel dependen yaitu pola pangan harapan dapat dijelaskan oleh variabel independen yaitu pengeluaran perkapita, besaran keluarga, dan tingkat pendidikan sedangkan sisanya sebanyak 3\% dijelaskan oleh variabel lain di luar model. Berdasarkan nilai Probability F adalah 0,02 sehngga nilianya kurang dari alpha. nilai sig-F $(\mathrm{p}<0,05)$ menunjukan bahwa Ho ditolak. Maka variabel independen yaitu pengeluaran perkapita, besaran keluarga, dan tingkat pendidikan secara bersama-sama berpengaruh secara signifikan terhadap pola pangan harapan di DIY.

Variabel independen yang memiliki pengaruh terhadap pola pangan harapan adalah pengeluaran perkapita, besaran keluarga dan tingkat pendidikan. Pengeluaran perkapita dan tingkat pendidikan memiliki pengaruh positif terhadap pola pangan harapan sedangkan besaran keluarga memiliki pengaruh negatif terhadap pola pangan harapan. Hasil olah data menunjukan bahwa nilai probability- $t$ pengeluaran perkapita memiliki nilai kurang dari alpha sehingga berpengaruh terhadap pola pangan harapan. Peningkatan pengeluaran perkapitas sebanyak 1 persen akan meningkatan pola pangan harapan DIY sebanyak $2,86 \%$. Harapannya dengan meningkatnya pengeluaran perkapita dapat dialokasikan dengan pemenuhan pangan yang cukup, sehingga meningkatnya pengeluaran perkapita juga sebanding dengan peningkatan pendapatan rumah tangga yang meningkat juga. Pengeluaran perkapita yang tinggi harapannya juga meningkatnya kualitas pangan yang terkonsumsi. Akan tetapi pengeluaran perkapita untuk konsumsi pangan sebaiknya tidak lebih besar dari konsumsi non pangannya.

Besaran keluarga berpengaruh positif terhadap pola pangan harapan jika ditinjau dari olah data pada tabel 2. Nilai signifikansi besaran keluarga lebih kecil dari alpha $(0,00<0,05)$ sehingga berpengaruh terhadap pola pangan harapan. Nilai koefisien besaran keluarga bernilai negatif sehingga peningkatan $1 \%$ besaran keluarga akan menurunkan pola pangan harapan DIY sebanyak 0,15\%. Undang-Undang Republik Indonesia no.21 tahun 1994 tentang Penyelenggaraan Pembangunan Keluarga Sejahtera pada pasal 6, salah satu cara dalam mencapai kenaikan status gizi keluarga dilakukan dengan pengembangan kualitas keluarga dengan mengikuti program pemerintah yaitu KB (Keluarga Berencana). 
Program keluarga berencana mengatur jumlah dan jarak anggota keluarga ideal. Semakin tinggi nilai skor pola pangan harapan semakin sejahtera pula keluarganya. Besar kecilnya suatu keluarga dalam hal ini diwujudkan dalam jumlah anggota keluarga menyebabkan distribusi makanan tidak merata satu sama lain, sehingga mempengaruhi pola konsumsi pangan dan status gizi masing masing anggota keluarga. Hal ini sejalan dengan teori Soetjiningsih (1995) dimana ekonomi akan lebih menguntungkan pada keluarga yang jumlah anggotanya kecil. Disisi lain pemenuhan akan kebutuhan pangan juga akan terpenuhi pada keluarga kecil jika dibandingkan dengan keluarga besar.

Berdasarkan tabel 2 dapat diketahui bahwa tingkat pendidikan memiliki pengaruh terhadap pola pangan harapan Daerah Istimewa Yogyakarta. Hasil analisis menyebutkan bahwa nilai signifikansi tingkat pendidikan sebesar 0,018. Hasil tersebut kurang dari nilai alpha $(0,0018<0,05)$ sehingga tingkat pendidikan berpengaruh terhadap pola pangan harapan. Jika ditinjau dari nilai koefisiennya bernilai 0,42 sehingga memiliki pengaruh positif terhadap pola pangan harapan DIY. Peningkatan tingkat pendidikan sebesar $1 \%$ akan meningkatkan skor pola pangan harapan DIY sebesar 0,42\%. Hal tersebut sejalan dengan teori Soegeng Santoso (1999), bahwa tingkat pendidikan yang tinggi memungkinkan seseorang memilih kategori makanan yang akan dikonsumsi berdasarkan ilmu yang diketahuinya. Hal tersebut biasanya sejalan dengan skor pola pangan harapan yang dimiliki juga akan baik. Semakin tinggi pendidikan anggota keluarga cenderung akan meningkatkan skor pola pangan harapan keluarga, khususnya saja oleh seorang ibu yang notabene menjadi juru masak dan yang memilihkan makanan apa saja yang akan dikonsumsi oleh keluarganya. Tingkat pendidikan dalam keluarga khususnya seorang ibu dapat menjadi faktor yang sangat mempengaruhi status gizi anak dalam keluarga. Semakin tinggi pendidikan orang tua maka pengetahuannya gizi menjadi lebih baik dibandingkan dengan yang berpendidikan rendah (Ngaisyah, 2017). Jika pengetahuan baik, status gizi keluarga akan meningkat karena pola konsumsi dan keragaman pangan sudah terpenuhi (Achmad Djaeni S, 2000).

\section{KESIMPULAN}

Hasil penelitian menunjukan bahwa perkembangan pola pangan harapan DIY mengalami peningkatan dari tahun 2016 hingga tahun 2018 dan mengalami penurunan di tahun 2019 dan di prediksi akan mengalami peningkatan kembali di tahun 2019. Hasil penelitian juga menunjukkan bahwa pengeluaran perkapita, besaran keluarga dan tingkat pendidikan berpengaruh positif terhadap pola pangan harapan Daerah Istimewa Yogyakarta. Apabila besaran keluarga, pengeluaran perkapita dan tingkat pendidikan porsinya meningkat maka PPH di DIY juga akan meningkat. Dalam rangka mewujudkan ketahanan pangan dalam hal ini dilihat dari skor pola pangan harapan perlu dilakukan penganekaragaman konsumsi makanan atau diversifikasi pangan sehingga pemenuhan kebutuhan konsumsi tidak hanya diperoleh dari pola konsumsi padi-padian. Selain itu upaya peningkatan pendapatan juga bisa dilakukan akan tetapi alangkah lebih baik apabila dalam keluarga tersebut pengeluaran pangannya lebih sedikit daripada pengeluaran non pangan. Besaran keluarga juga harus proposional untuk meningkatkan ketahanan pangan dan mevariasikan pola konsumsi makanannya didukung dengan tingkat pendidikan masing-masing anggota keluarga. Selain itu tingkat pendidikan juga berpengaruh terhadap konsumsi seseorang. Semakin tinggi pendidikan seseorang semakin jeli juga dalam mengkonsumsi suata makanan karena pengetahuan makanan akan semakin luas. 


\section{Ucapan Terima Kasih}

Penulis mengucapkan terimakasih yang sebanyak-banyaknya kepada semua pihak yang telah membantu dan mendukung, baik dari pendanaan, waktu dan tenaga. Sehingga penelitiian dengan judul "Perkembangan dan Faktor-faktor yang Mempengaruhi Pola Pangan Harapan Daerah Istiewah Yogyakarta" dapat terlaksana dengan baik.

\section{DAFTAR PUSTAKA}

Achmad Djaeni Sediaoetama. 2000. Ilmu Gizi untuk Mahasiswa dan Profesi di Indonesia Jilid I. Jakarta: Penerbit Dian Rakyat

Al-Rahmad AH, Fadillah I. 2016. Perkembangan Psikomotorik Bayi 6-9 Bulan berdasarkan Pemberian ASI Eksklusif. Aceh Nutrition Journal. 1(2):99-104.

Al Rahmad AH, Almunadia A. 2017. Pemanfaatan Media Flipchart dalam Meningkatkan Pengetahuan Ibu Tentang Konsumsi Sayur dan Buah. Jurnal Kedokteran Syiah Kuala. 17(3):140-146.

Amaliyah, H dan Sugiharti, M.H. 2011. Analisis Hubungan Proporsi Pengeluaran dan Konsumsi Pangan dengan Ketahanan Pangan Rumah Tangga Petani Padi di Kabupaten Klaten. Jurnal Sosial Ekonomi Pertanian dan Agribisnis, 7(2):110-118

Aneftasari, IR. Arifin, B. Indriani, Y. 2016. Determinan Pola Pangan Harapan Pada Rumah Tangga Buruh Pengasin Ikan di Pulau Pasaran. JIIA. Vol 4 (3). 301-308

Argandi, S. Trimo, L. Noor, TI. 2019. Faktor-Faktor Yang Mempengaruhi Pola Pangan Harapan (PPH) di Kabupaten Bandung. Jurnal Ilmiah Mahasiswa AGROINFO GALUH. Vol 6 (1). 132-143.

Badan Ketahanan Pangan. 2016. Laporan Tahunan Badan Ketahanan Pangan 2015. Jakarta: Kementerian Pertanian

Badan Pusat Statistik Provinsi Daerah Istimewa Yogyakarta. 2019. Data Pola Pangan Harapan Daerah Istimewa Yogyakarta. Badan Pusat Statistik: Daerah Istimewa Yogyakarta.

Bappenas. Laporan Pencapaian Tujuan Pembangunan Milenium Di Indonesia 2014. Kesembilan. Jakarta: Kementerian Perencanaan Pembangunan Nasional; 2015.

Bappenas. 2014. Data Impor Pangan Indonesia.

Budioro. 1997. Pengantar Administrasi Kesehatan Masyarakat. Semarang : FKM Undip

Draper, N.R. and Smith, H. 1992. Applied Regression Analysis,Second Edition. John Wiley and sons, Inc. New York.

FAO-RAPA. 1998. Report Of The Regional Expert Consultation of The Asian Network for Food and Nutrition and Urbanization. Bangkok

Kemenkes. RI. 2015. Rencana Strategis Kementerian Kesehatan Tahun 20152019: Keputusan Menteri Kesehatan Republik Indonesia No: HK.02.02/MENKES/52/2015. Jakarta : Kementerian Kesehatan RI

Kementerian Pertanian. 2010. Analisis Pola Pangan Harapan (PPH).

Latifah, Nurul. Susanti, Y. Haryanti, D. 2018. Hubungan Dukungan Keluarga Dengan Status Gizi Pada Balita. Jurnal Keperawatan. Vol 10 (1). 68-74

Nazir, M. 1988. Metode Penelitian. Jakarta: Ghalia Indonesia. 
Ngaisyah, Dewi. 2017. Keterkaitan Pola Pangan Harapan (Pph) dengan Kejadian Stunting Pada Balita. Jurnal Kedokteran dan Kesehatan. Vol 13 (1). 71-79

Rah JH, Akhter N, Semba RD, De Pee S, Bloem MW, Campbell AA, MoenchPfanner R, Sun K, Badham J, Kraemer K. 2010. Low dietary diversity is a predictor of child stunting in rural Bangladesh. European journal of clinical nutrition. 64(12):1393-1398.

Singarimbun, Masri. 1983. Metode Penelitian Survei. CV Rasma Agung, Jakarta.

Soetjiningsih. 1995. Tumbuh Kembang Anak. Buku Kedokteran. Jakarta

Sugiyono, 2012. Metode Penelitian Kuantitatif, kualitatif dan kombinasi (mixed methods). Penerbit Alfabeta. Bandung.

Sunyoto Usman. 2004. Politik Pangan. Yogjakarta: (Cired) Center for Indonesian Research and Development

Suryana, Roudza, Alfridsyah. 2016. Konsumsi Pangan dan Skor Pola Pangan Harapan (PPH) Dengan Prevalensi Stunting di Provinsi Aceh. Aceh Nutrition Journal. Vol 3 (2). 149-157

Undang- undang Nomor 21 Tahun 1994 tentang Penyelenggaraan Pembangunan Keluarga Sejahtera

WHO.(2013). World Mortality Report 2013. ST/ESA/SER.A/347. New York: United Nations 